\title{
The Influence of Calcium Sprays to Reduce Fungicide Inputs Against Apple Scab (Venturia inaequalis (Cooke) G. Wint.)
}

\author{
Glynn C. Percival and lan Haynes
}

\begin{abstract}
A goal of pathogen management in the arboriculture industry should be to eliminate or reduce the amount of active ingredients of synthetic fungicides used within a growing season. The aim of this research paper was to evaluate a nonfungicidal pathogen management system by investigating the hypothesis that replacing an apple scab fungicide spray program with calcium reduces fruit and leaf scab severity. In addition, a separate study investigated if a relationship existed between calcium concentrations within foliar tissue of resistant, intermediate, and sensitive apple species and varieties toward scab infection. A number of commercially available calcium products were applied to apple cv. Crown Gold trees at four distinct growth stages (bud break, $90 \%$ petal fall, early fruitlet, two weeks after early fruitlet). A comparative evaluation of the synthetic fungicide penconazole commercially used for scab control was also conducted. The experiment was performed in 2006 and repeated in 2007 at the University of Reading Experimental Field Site (UK). Application of calcium sprays significantly reduced the leaf and fruit scab severity of apple cv. Crown Gold however; in a separate study no relationship existed between foliar calcium content and susceptibility to apple scab attack between resistant, intermediate, and sensitive Malus species. Greatest protection in both field trials was provided by the synthetic fungicide penconazole. Within the calcium products evaluated, greatest protection in both field trials was provided by calcium chloride and calcium hydroxide. The integration of calcium foliar sprays into existing scab management practices offers a useful addition to reduce scab severity on ornamental apples that has applicability against other foliar diseases frequently encountered within urban landscapes.

Key Words. Fruit; Holistic Approach; Integrated Disease Management; Pathogen Control; Plant Health Care; Urban Landscapes.
\end{abstract}

During their life cycle, urban trees are susceptible to attack by several foliar pathogens. If uncontrolled, these attacks will result in high mortality rates and/or undesirable reductions in tree aesthetic appearance. For example, apple scab represents a worldwide problem of fruiting and ornamental apples planted into UK, U.S., and European landscapes. Initial infection appears as olivegreen to sooty or smudgy spots on the leaf surface or leaf petiole. On older leaves, the infected areas form definite spots, which are slightly raised, black, and velvety in appearance. As the infection develops, the leaves turn yellow and drop prematurely. Premature defoliation makes the tree aesthetically undesirable and greatly weakens it. Infected fruit becomes deformed, scabby, and usually drops before maturity (Cuthbertson and Murchie 2003). As suppliers and growers of apples generally adopt a zero tolerance policy towards scab, any scab infection reduces tree quality and marketable yield (Percival and Boyle 2005). Consequently, the economics of fruit and ornamental tree production require frequent application of synthetic fungicides throughout the growing season (Berrie and Xu 2003). As strains of pathogenic fungi resistant to synthetic fungicides develop, coupled with increased public concern over pesticide residues and the fact that arborists manage trees in densely populated areas where potential fungicide contact with pedestrians could lead to litigation claims, new approaches to pathogen management are needed (Christiansen et al. 1999; Percival 2001; Percival and Haynes 2008).

Calcium is a major macronutrient in trees, important to the structural integrity of cell walls and plasma membranes, as well as maintaining membrane integrity and transport func- tion (Steponkus 1984). Calcium is additionally involved with nitrate uptake and metabolism, enzyme activity and starch metabolism. Because calcium is immobile in the phloem, calcium-based fertilizers are widely used by the orchard industry to reduce calcium-deficient fruit disorders such as bitter pit of apples, cork spot of pears, as well as ensuring optimal soil $\mathrm{pH}$ for tree growth (Raese 1997). However, there is also a growing body of evidence noting that enhanced calcium concentrations in leaf, stem, and root tissue by calcium fertilization can aid in reducing pathogen severity caused by several fungi and bacteria. Pertinent examples include enhanced resistance against soft rot of potato caused by Erwinia carotovora subsp. amylovora (McGuire and Kelman 1984; McGuire and Kelman 1986; Bain et al. 1996), Phoma exigua (gangrene) and Fusarium solani (dry rot) of potato (Olsson 1998), Botrytis cinerea of apple (Conway et al. 1991), sweet cherries (Ippolito et al. 2005), and brown rot of peach caused by Monilinia fructicola (Elmer et al. 2006).

Recent research also indicates the form of calcium is potentially important for disease suppression (Elmer et al. 2006). For example, calcium nitrate reduced the incidence of brown rot of cherries in two of a three-year trial while calcium chloride forms had no effect on brown rot incidence (Wojcik 2001). Commercially, a wide range of calcium fertilizers exist to include calcium nitrate, calcium sulfate, calcium chloride, etc. The efficacy of many of these calcium products has not been evaluated for their potential in foliar pathogen suppression. The objectives of this research were to evaluate the effectiveness and feasibility of commercially available calcium fertilizers on suppressing severity 
of apple scab on leaf and fruit tissue, and investigate the relationship of foliar calcium content within resistant, intermediate, and sensitive apple species on resistance against apple scab to determine if analyzing foliar calcium concentrations provides a means of screening new cultivars for their scab sensitivity.

\section{MATERIALS AND METHODS}

\section{Field Experiment}

The apple trial site consisted of a 1.5 ha block of apple (Malus cv. Crown Gold) interspersed with individual trees of Malus 'Red Delicious' and 'Gala' as pollinators. Planting distances were based on $3 \mathrm{~m}(9.9 \mathrm{ft})$ by $3 \mathrm{~m}(9.9 \mathrm{ft})$ spacing. The trees were planted in 1979 and trained as an open leader (i.e., bush shaped tree by periodically pruning the central leader). All experimental trees had an average height of $2 \pm 0.2 \mathrm{~m}(6.6 \pm 0.6 \mathrm{ft})$ with mean butt diameters of $33 \pm 5 \mathrm{~cm}(13.2 \pm 2 \mathrm{in})$ at $45 \mathrm{~cm}$ (17.7 in) above the soil level. The trial site was located at the University of Reading Shinfield Experimental Site, University of Reading, Berkshire ( $51^{\circ} 43$ $\left.\mathrm{N},-1^{\circ} 08 \mathrm{~W}\right)$. The soil was a sandy loam containing $4 \%-6 \%$ organic matter, $\mathrm{pH}$ of 6.1 , available $\mathrm{P}, \mathrm{K}, \mathrm{Mg}, \mathrm{Na}$, and $\mathrm{Ca}$ were 55.3, 702.4, 188.2, 52.9 and $1888 \mathrm{mg}$ per liter $(0.0001,0.004,0.002$, $0.0001,0.02 \mathrm{oz}$ per gallon). Site management consisted of a $2 \mathrm{~m}$ $(6.6 \mathrm{ft})$ wide, weed-free strip beneath the trees maintained with glyphosate (Roundup; Green-Tech, Sweethills Park, Nun Monkton, York, UK). Trees were irrigated with under-tree impact sprinklers at 10-day intervals throughout the growing season. No supplementary fertilization was applied during the trials. A minimal insecticide (deltamethrin, product name Bandu, Headland Agrochemicals Ltd, Saffron Walden, Essex, UK) program was applied every two months during the growing season commencing in May 2006 (Nicholas et al. 2003), a standard practice followed at the University of Reading experimental site for orchard pest control. All sprays were applied using a Tom Wanner Spray Rig sprayer at $40 \mathrm{ml}(1.4 \mathrm{fl} \mathrm{oz})$ deltamethrin per $100 \mathrm{~L}(26.4 \mathrm{gal})$ of water. Trees were sprayed until runoff, generally $3.5 \mathrm{~L}(0.9 \mathrm{gal})$ per tree.

\section{Calcium Treatments}

A randomized complete block was utilized in the experimental design. Ten treatments included seven calcium products (calcium chloride, calcium sulfate, calcium nitrate, calcium nitrate borate, calcium hydroxide, calcium metalosate, calcium magnesium complex) (United Agri-Products, Alconbury Weston, Huntingdon, UK), one Silwett L77 (80\% polyalkylene oxide, $20 \%$ allyloxypolyethylene glycol methyl, ether plant penetrant; De Sangosse, Swaffham Bulbeck, Cambridge, UK), one conventional fungicide (penconazole), and a water control. These 10 treatments were assigned to eight single-tree replications, totaling 80 observations per response variable.

Calcium sprays were applied using a 5 L (1.32 gal) pump-action sprayer and trees were sprayed until runoff. Single-row borders prevented overspray of calcium treatments and double-row borders prevented calcium drift. Calcium treatments were applied at bud break (March 11, 2006 and March 22, 2007), 90\% petal fall (May 13, 2006 and May 27, 2007), early fruitlet (June 2, 2006 and June 7, 2007), and two weeks after early fruitlet (June 16, 2006 and June 21, 2007). Each calcium spray was calibrated so each tree received $2.5 \mathrm{~g}(0.09 \mathrm{oz})$ calcium per spray [10 g (0.75 oz) total].

Poor absorption and uptake of foliar applied calcium is a widely recognized problem within the orchard industry. Consequently calcium sprays are routinely applied in combination with a plant penetrant such a Silwett L77. Silwett L77 was applied singly and in combination with all calcium fertilizers at the manufacturers recommended rate, $5 \mathrm{ml}$ (1 tsp) per ten liter (2.6 gal). A comparative evaluation of the synthetic fungicide penconazole (10\% emulsfiable concentrate), a protectant triazole fungicide with antisporulant activity commercially used for apple scab control, was conducted by spraying trees at the recommendation the manufacturers (Syngenta Crop Protection UK Ltd, Whittlesford, Cambridge, UK), at the rate of $1.5 \mathrm{ml}(0.045 \mathrm{fl} \mathrm{oz})$ per liter of water.

\section{Leaf and Fruit Scab Severity}

Historically, the apples heavily suffered from apple scab infection on an annual basis. As a result, before the trial commencing in 2006 and 2007, trees were inspected in September 2005 and 2006; and only those trees with $50 \%-80 \%$ of leaves affected, severe foliar discoloration, and subsequent scab infection were used. During the trials, assessment of scab severity of leaves and fruit commenced each September. Leaf scab severity of each tree was rated using a visual indexing technique and ratings on the scale: $0=$ No scab observed; $1=$ less than $5 \%$ of leaves affected and no aesthetic impact; $2=5 \%-20 \%$ of leaves affected with some yellowing but little or no defoliation; $3=21 \%-50 \%$ of leaves affected, significant defoliation and/or leaf yellowing; $4=51 \%-80 \%$ of leaves affected, severe foliar discoloration; $5=81 \%-100 \%$ of leaves affected with $90 \%-100 \%$ defoliation. Scab severity on fruit was calculated on the scale: $0=$ no visible lesions; $1=<10 \%$ fruit surface infected; $2=10 \%-25 \%$ fruit surface infected; $3=$ $>25 \%-50 \%$ fruit surface infected; $4=>50 \%$ fruit surface infected. The individual ratings for each tree in each treatment were used as a measure of scab severity for statistical analysis. Leaf scab severity ratings used in this study were based on UK and Ireland market standards for fungicide evaluation of scab control (Butt et al. 1990; Swait and Butt 1990). Fruit scab severity was based on a scale used by Ilhan et al. (2006). Scab severity ratings were undertaken by three independent BASIS (British Agrochemical Standards Inspection Scheme) qualified crop protection specialists.

\section{Chlorophyll Fluorescence}

Prior to measurement, ten leaves per tree randomly selected throughout the crown were adapted to darkness for $30 \mathrm{~min}$ by attaching light exclusion clips to the leaf surface and chlorophyll fluorescence was measured using a HandyPEA portable fluorescence spectrometer (Hansatech Instruments Ltd, King's Lynn, UK). Measurements were recorded up to one second with a data acquisition rate of $10 \mu \mathrm{s}$ for the first two ms, and of one ms thereafter. The fluorescence responses were induced by a red (peak at $650 \mathrm{~nm}$ ) light of $1500 \mu \mathrm{mol} \mathrm{m} \mathrm{m}^{-2} \mathrm{~s}^{-1}$ photosynthetically active radiation (PAR) intensity provided by an array of six light-emitting diodes. The ratio of variable $(\mathrm{Fv}=\mathrm{Fm}-\mathrm{Fo})$ to maximal (Fm) fluorescence (i.e., Fv/Fm where Fo = minimal fluorescence) of dark adapted leaves were used to quantify the detrimental effects of fungal infection on tree vitality. Fv/Fm is considered a quantitative measure of the maximal or potential photochemical efficiency or optimal quantum yield of photosystem II (Willits and Peet 2001) and consequently the most popular index used as a measure of plant vitality and early diagnostic of stress (Meinander et al. 1996). The ten leaf values per tree were pooled to provide a mean for each tree for statistical purposes. 


\section{Chlorophyll Measurements}

A Minolta chlorophyll meter SPAD-502 was used. Chlorophyll was measured at the midpoint of the leaf next to the main leaf vein. Calibration was obtained by measurement of absorbance at 663 and $645 \mathrm{~nm}$ in a spectrophotometer (PU8800 Pye Unicam) after extraction with $80 \% \mathrm{v} / \mathrm{v}$ aqueous acetone (regression equation $=5.92+0.060 \mathrm{x} ; \mathrm{r}^{2}$ adj $\left.=0.92, \mathrm{P}=<0.01\right)($ Lichtenthaler and Wellburn 1983). Ten leaves per tree randomly selected throughout the crown were used for measurements, and the mean per tree was calculated for statistical purposes.

\section{Relationship Between Leaf Calcium Content and Scab Resistance}

\section{Collection of Leaf Material for Calcium Analysis}

Mature, fully expanded leaves near the top of the canopy (generally about the fourth leaf from the apex) of a range of Malus species-eight trees per species_classified as resistant ( $M$. 'Red Jade', $M$. huphensis, $M$. floribunda, $M$. 'Profusion'), intermediate (M. sargentii, $M$. 'Golden Delicious', $M$. 'Royalty', $M$. 'Indian Magic'), and sensitive (M. × purpurea 'Eleyi.', $M$. 'Cox's Orange Pippin', $M$. 'Hopa', $M$. 'Red Delicious') to apple scab (Durham et al. 1999) was collected in early May $c a$. six weeks after leaf flush - a time when leaves show maximum photosynthetic performance (Kitao et al. 1998) with no visible signs of apple scab.

Leaf material was collected from a range of local commercial suppliers of ornamental apple located within the Reading area. Collected leaves were transported in insulated boxes sheltered from light, and all material prepared within two hours of collection. Leaf calcium content of calcium and penconazole treated trees was analyzed in the same manner only in this instance leaves were collected at Week 2 following the final calcium and penconazole spray treatment.

\section{Calcium Content Assessment}

Eight trees per calcium treatment, with twelve leaf samples per tree, were selected at random from the canopy and pooled to form sufficient material for calcium analysis. Samples were then thoroughly washed, dried in a convection oven at $85^{\circ} \mathrm{C}$ $\left(185^{\circ} \mathrm{F}\right)$ for 48 hours before being ground through a $0.5 \mathrm{~mm}$ (0.02 in) cyclone mill (Retsch, Middlesborough, UK). Each separate sample $[0.5 \mathrm{~g}(0.02 \mathrm{oz})]$ was placed into $150 \mathrm{ml}(5 \mathrm{fl}$ oz) volumetric flasks and digested in $20 \mathrm{ml}(0.7 \mathrm{fl} \mathrm{oz})$ of $7: 1 \mathrm{ni}-$ tric/perchloric acid. After cooling, the solutions were brought to volume with deionized water and analyzed by Inductively Coupled Plasma-Emission Spectroscopy (ICP) elemental analysis. Calcium values were expressed as \% total leaf dry weight.

\section{Data Analysis}

Data were analyzed using Genstat 8. Levene's (1960) test was used to determine the homogeneity of variances, and data were transformed $[\log (y+0.5)]$ when necessary. Visual severity index data were transformed using arcsine [sqrt $(y / 100)]$. Treatment significance from controls was separated using Fisher's least significant difference (LSD) at the $P<0.05$ level. Correlation equations and coefficients of multiple determination $\left(\mathrm{r}^{2}\right)$ of foliar calcium content against leaf scab severity at the cessation of the growing season (September) were calculated using the curve fitting feature of Genstat V. A linear model was used for correlation analysis as this model provided the highest percentage goodness of fit.

\section{RESULTS}

\section{Field Trials}

Irrespective of year, no significant influence of the plant penetrant Silwett L77 used to facilitate entry of calcium ions into the leaf was recorded (Table 1; Table 2). Measurements of leaf and fruit scab severity, chlorophyll fluorescence $\mathrm{Fv} / \mathrm{Fm}$ values, leaf chlorophyll content SPAD values, and foliar calcium content were, in all cases, not significantly $(P<0.05)$ different from noncalcium treated control trees (Table 1; Table 2). Applications of calcium sprays in virtually all instances had a significant influence on foliar and fruit scab severity, chlorophyll fluorescence $\mathrm{Fv} / \mathrm{Fm}$ values, leaf chlorophyll content SPAD values and foliar calcium content (Table 1; Table 2). Application of calcium

Table 1. Selected calcium foliar sprays compared for the control of apple scab (Venturia inaequalis) on apple cv. Crown Gold as measured by leaf and fruit scab severity, chlorophyll fluorescence (Fv/Fm values), leaf chlorophyll content (SPAD values), and leaf Ca content. Data from 2006.

\begin{tabular}{|c|c|c|c|c|c|}
\hline Treatment & $\begin{array}{l}\text { Leaf scab } \\
\text { severity }^{z}\end{array}$ & $\begin{array}{l}\text { Fruit } \\
\text { scab severity }\end{array}$ & $\mathrm{Fv} / \mathrm{Fm}^{\mathrm{y}}$ & SPAD $^{y}$ & $\begin{array}{l}\text { Leaf Ca } \\
\text { content }^{\mathrm{z}}\end{array}$ \\
\hline Control & 3.50 & 2.85 & 0.723 & 12.26 & 1.22 \\
\hline Silwett & $3.62 \mathrm{~ns}$ & $2.50 \mathrm{~ns}$ & $0.713 \mathrm{~ns}$ & $15.69 \mathrm{~ns}$ & $1.24 \mathrm{~ns}$ \\
\hline Calcium sulfate & $2.50 *$ & $2.75 \mathrm{~ns}$ & $0.803 *$ & $18.34 *$ & $1.39 *$ \\
\hline Calcium nitrate & $3.00 \mathrm{~ns}$ & $1.75^{*}$ & $0.797 \mathrm{~ns}$ & $14.3 \mathrm{~ns}$ & $1.51 *$ \\
\hline Calcium nitrate borate & $2.50 *$ & $2.13^{*}$ & $0.800 \mathrm{~ns}$ & $13.05 \mathrm{~ns}$ & $1.46^{*}$ \\
\hline Calcium hydroxide & $2.13 *$ & $1.50^{*}$ & $0.799 \mathrm{~ns}$ & $18.70 *$ & $1.58 *$ \\
\hline $\begin{array}{l}\text { Calcium amino acid } \\
\text { complex }\end{array}$ & $2.38^{*}$ & $2.25 \mathrm{~ns}$ & $0.793 \mathrm{~ns}$ & $18.75^{*}$ & $1.59 *$ \\
\hline Penconazole & $1.70^{*}$ & $1.00^{*}$ & $0.811^{*}$ & $20.51 *$ & $1.24 \mathrm{~ns}$ \\
\hline DF & 79 & 79 & 79 & 79 & 79 \\
\hline LSD & 0.826 & 0.678 & 0.082 & 3.86 & 0.134 \\
\hline $\begin{array}{l}\text { Significance of } \mathrm{Ca} \\
(P \text { value })\end{array}$ & 0.002 & $<0.001$ & 0.059 & $<0.001$ & $<0.001$ \\
\hline
\end{tabular}

${ }^{\mathrm{z}}$ Values mean of 8 trees.

y Values mean of 8 trees, 10 leaves per tree.

Asterisk (*) indicates value significantly different from controls according to Least Significant Difference (LSD) at $P<0.05$.

$\mathrm{ns}=$ not significant different from control value. 
Table 2. Selected calcium foliar sprays compared for the control of apple scab (Venturia inaequalis) on apple cv. Crown Gold as measured by leaf and fruit scab severity, chlorophyll fluorescence (Fv/Fm values), leaf chlorophyll content (SPAD values), and leaf Ca content. Data from 2007.

\begin{tabular}{|c|c|c|c|c|c|}
\hline Treatment & $\begin{array}{l}\text { Leaf } \\
\text { necrosis }^{z}\end{array}$ & $\begin{array}{l}\text { Fruit } \\
\text { necrosis }^{z}\end{array}$ & $\mathrm{Fv} / \mathrm{Fm}^{\mathrm{y}}$ & SPAD $^{y}$ & $\begin{array}{l}\text { Leaf Ca } \\
\text { content }^{2}\end{array}$ \\
\hline Control & 4.00 & 3.00 & 0.715 & 11.69 & 1.21 \\
\hline Silwett & $3.88 \mathrm{~ns}$ & $2.88 \mathrm{~ns}$ & $0.702 \mathrm{~ns}$ & $13.85 \mathrm{~ns}$ & $1.24 \mathrm{~ns}$ \\
\hline Calcium chloride & $1.63^{*}$ & $1.25^{*}$ & $0.807^{*}$ & $19.00 *$ & $1.45^{*}$ \\
\hline Calcium sulfate & $2.25^{*}$ & $3.12 \mathrm{~ns}$ & $0.780 \mathrm{~ns}$ & $16.45^{*}$ & $1.36^{*}$ \\
\hline Calcium nitrate & $2.62 *$ & $2.25^{*}$ & $0.783 \mathrm{~ns}$ & $15.76^{*}$ & $1.50^{*}$ \\
\hline Calcium hydroxide & $1.88^{*}$ & $1.88 *$ & $0.791 \mathrm{~ns}$ & $18.00 *$ & $1.51 *$ \\
\hline Calcium metalosate & $2.25 *$ & $2.38 *$ & $0.785 \mathrm{~ns}$ & $12.69 \mathrm{~ns}$ & $1.39 *$ \\
\hline $\begin{array}{l}\text { Calcium amino acid } \\
\text { complex }\end{array}$ & $2.13^{*}$ & $2.50 \mathrm{~ns}$ & $0.779 \mathrm{~ns}$ & $16.18^{*}$ & $1.57 *$ \\
\hline Penconazole & $1.45^{*}$ & $1.00 *$ & $0.805^{*}$ & $21.30 *$ & $1.26 \mathrm{~ns}$ \\
\hline $\mathrm{DF}$ & 79 & 79 & 79 & 79 & 79 \\
\hline LSD & 0.722 & 0.556 & 0.091 & 2.708 & 0.146 \\
\hline
\end{tabular}

${ }^{z}$ Values mean of 8 trees

${ }^{\mathrm{y}}$ Values mean of 8 trees, 10 leaves per tree.

Asterisk (*) indicates value significantly different from controls according to Least Significant Difference (LSD) at $P<0.05$.

$\mathrm{ns}=$ not significant different from control value.

sprays at four times during the growing season, significantly $(P$ $<0.05)$ reduced apple scab severity of leaves and fruit at harvest maturity (September) from an average of 3.50 and 2.85 (2006) and 4.00 and 3.00 (2007), to 2.4 and 1.98 (2006), and 2.14 and 2.26 (2007) respectively, when averaged across all seven calcium treatments compared to the noncalcium control treatment

A difference in the magnitude of scab severity reductions between calcium products was recorded. In both the 2006 and 2007 trials, only apple trees treated with calcium chloride and calcium hydroxide had significantly $(P<0.05)$ less leaves and fruit with scab compared to untreated control trees (Table 1; Table 2). This indicates that out of all the seven commercially available calcium products tested, calcium chloride and calcium hydroxide provided greatest protection against apple scab on both leaves and fruit. Maximal reductions in scab severity of leaves and fruit in both the 2006 and 2007 trials was, however, achieved by applying sprays of the commercially recommended synthetic fungicide penconazole. In this instance, leaf and fruit severity was reduced by $51 \%$ and $65 \%$ in the 2006 trial, and by $54 \%$ and $67 \%$ in the 2007 trial, respectively (Table 1; Table 2). In both the 2006 and 2007 trials, applications of calcium and penconazole increased chlorophyll fluorescence Fv/Fm values in comparison with noncalcium treated controls indicating higher leaf photosynthetic activity in calcium and penconazole treated trees (Table 1; Table 2). In only three instances, however, were these increases significant, application of penconazole, calcium chloride (2006 and 2007) and calcium sulfate (2006 only). Likewise in both the 2006 and 2007 trials applications of calcium and penconazole increased chlorophyll content SPAD values compared with noncalcium treated controls indicating less damage to the leaf chlorophyll molecule at the cessation of the growing season (Table 1; Table 2). Mostly, this increase was statistically significant at $P<0.05$, indicating that resistance to infection had been enhanced. In all cases, applications of calcium, irrespective of form, significantly
$(P<0.05)$ increased calcium concentration within leaf tissue by ca. $11 \%-25 \%$ in the 2006 trial (Table 1) and $12 \%-23 \%$ in the 2007 trial (Table 2) when averaged across all calcium treatments. Application of the synthetic fungicide penconazole had no significant effect on leaf calcium content (Table 1; Table 2).

\section{Relationship Between Foliar Calcium Content and Scab Severity}

There was no clear relationship between leaf calcium content and the degree of apple scab susceptibility. For reasons of clarity, data for five of the twelve species tested are shown in Figure 1. In this instance, percent variation accounted for recorded was $4 \%$ that was not significant; $\mathrm{P}=0.179$. Such a response reflects that recorded for all twelve species (percent variation accounted for recorded $=7 \%, \mathrm{P}=0.166$, data not shown), and in Figure 1 where highest leaf calcium content $(1.4 \%-1.9 \%$ dry weight) was recorded in foliar tissue derived from $M$. 'Cox's Orange Pippin' yet scab susceptibility ranged from 3-5 on a scab severity scale indicative of a scab sensitive species. Contrary to this lowest leaf calcium content (1\%-1.3\% dry weight) was recorded in foliar tissue derived from $M$. 'Red Jade', yet scab susceptibility ranged from 1-3 on a scab severity scale indicative of a scab resilient species.

\section{DISCUSSION}

Increased concerns regarding the over reliance of fungicides for pathogen control, coupled with development of pathogen insensitivity, increased legislative restriction regarding fungicide use and greater public awareness of the potential environmental impact of synthetic pesticides has meant considerable research has been aimed at developing nonfungicidal approaches to pathogen control (Akbudak et al. 2006; Walters 2006; Hagan and Akridge 2007; Percival and Haynes 2008). The primary aim of this study was to determine whether appli- 


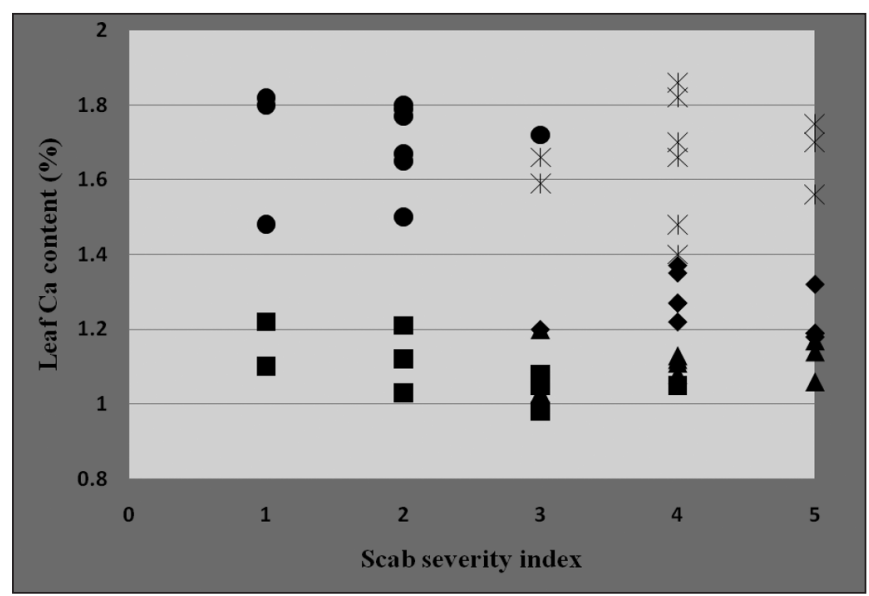

Figure 1. Correlation between leaf calcium content (leaves collected in early May ca. 6 weeks after leaf flush) and scab severity at the cessation of the growing season. Intercept (calculated) $=-\mathbf{0 . 0 4 0 3}$; Coefficient $=-1.50 ; r^{2}(\%$ variation accounted for $)=0.04 ; P$ value $=$ 0.179. $\Delta=M$. $\times$ purpurea 'Eleyi'; $\square=M$. 'Red Jade'; $\bullet=$ M. huphensis; $\mathrm{X}=$ M. 'Cox's Orange Pippin' $\bullet$ = M. 'Golden Delicious'.

cations of foliar applied calcium reduced the susceptibility of apple trees to infection by Venturia inaequalis, thereby providing arborists with an additional practical tool to complement or replace existing fungicide-based pathogen control programs.

Applying a range of calcium products at $2.5 \mathrm{~g}$ per tree, 10 $\mathrm{g}$ total, over the growing season, significantly increased the calcium content in the leaf tissue of apple Crown Gold with no evidence of phytotoxicity. However, there was no significant positive correlation between calcium content in leaves of a range of resistant, intermediate and sensitive apple species and scab severity at the cessation of the growing season. This is important from two points of view. First analysis of leaf calcium content of breeder's selections for scab resistant apple varieties could not be used for screening for improved resistance. Second, although application of calcium sprays reduced scab severity this does not appear to be due to the increased presence of calcium ions with leaf tissue. Contrary to this, increasing calcium content with plant tissues has been positively correlated with enhanced resistance against a range of fungal (Phoma exigua var foveata, Monilinia fructicola) and bacterial (Erwinia carotovora subsp atroseptica) pathogens (McGuire and Kelman 1984; McGuire and Kelman 1986; Bain et al. 1996). Increased resistance was shown to be due to calcium-induced, improved structural integrity of the cell wall and middle lamella that physically increased cell wall strength making host plants less susceptible to enzymatic degradation (Olsson 1998). Biggs et al. (1997) concluded increased calcium concentrations in the fruit skin of cherry enhanced cell wall resistance to enzymatic digestion from extra-cellular enzymes such as polygalacturonase produced by $M$. fructicola. Results of this study indicate that mechanical or physical protection induced by calcium has limited effect on apple scab severity.

However, application of calcium based fertilizers were useful in suppressing scab indicating that calcium sprays possess some forms of scab protectant properties. Although this investigation did not specifically investigate the mechanistic basis of enhanced resistance previous research suggests that one or several of the following biochemical mechanisms are involved. Calcium is also known to directly affect some fruit pathogens by interfering with spore germination, germ tube elongation, fungal cell wall thickness (Chardonnet et al. 1999; Miceli et al. 1999; Chardonnet et al. 2000) and the activity of pectolytic enzymes (Conway et al. 1991). For example, direct inhibition of polygalacturonase-a cell wall degrading enzyme produced by $M$. fructicola as a consequence of calcium application-slowed the infection process and allowed constitutive and induced host responses to protect the plant from infection (Forbes-Smith 1999). The synthesis of plant protectant phytoalexin and phenolics substances has been reported to increase as a result of calcium application (Kohle et al. 1985; Miceli et al. 1999). Other calcium based resistance mechanisms include calcium ions interfering with chemotaxic responses required for fungal infection, calcium induced abrasion of hyphae leading to ineffective infection and dilution of other nutrients at the plant surface that reduces pathogen vigor and growth rate (Glenn et al. 1999; Glenn et al. 2001). Pre-harvest micro-cracks in the cuticle of stone fruits have been identified as an important site of infection for Monilinia spp. in prunes (Michailides and Morgan 1997) and B. cinerea in sweet cherries (Børve et al. 1998) Because of this, it is a common practice amongst sweet cherry growers worldwide to apply calcium to reduce the risk of micro-cracking and pre-harvest fruit infection (Cline and Tehrani 1973; Børve et al. 2000). The effect of calcium on micro-cracks of apple fruit was not recorded in this investigation but may account for the significantly lower extent of scab severity recorded on fruit in both the 2006 and 2007 trials.

Additionally, application of calcium fertilizers to trees has been shown to induce a suite of morphological and physiological adaptations associated with enhanced tolerance to environmental stresses such as salinity, freezing, and elevated temperatures. In these instances, enhanced tolerance of calcium treated plants are achieved via alterations to the structural stability of cell walls and plasma membranes resulting from calcium links between phosphate and plasma lipids and a concomitant increase in physical cell wall strength (Legge et al. 1982). Calcium has also shown to have been important in controlling enzyme activity involved with freezing resistance, inducing formation of shock proteins in response to elevated temperatures, and regulating stomatal closure in response to excess salinity, in turn preventing an excess build-up of reactive oxygen species within the leaf photosynthetic system (Price 1990). Furthermore, low temperature stress increased levels of a calcium-dependent NAD kinase responsible for activating enzymes, causing the synthesis of proteins necessary to influence cold acclimation. The progress of freezing injury can also be halted by bathing or washing freeze-thaw injured tissue in calcium-based solutions (Monroy et al. 1993; Berbezy et al. 1996). Such improvements in tree vitality as a direct result of calcium fertilization may also have contributed to the reduced scab severity recorded in this study.

Of all seven calcium products evaluated, only trees treated with calcium chloride and calcium hydroxide had significantly less leaves and fruit with scab infection compared to untreated control trees in both the 2006 and 2007 trials, indicating calcium chloride and calcium hydroxide provided greatest protection against scab on both leaves and fruit. Differences in the extent of scab protection between commercially available calcium products are consistent with other research (Wojcik 2001), indicating that calcium form affects susceptibility of a plant to scab infection and the anion attachment (chloride, sulfate, nitrate etc.) may 
play an influential role in conferring protection. Wojcik (2001) concluded the anion was important in influencing plant calcium uptake and translocation, which in turn conferred greater protection against brown rot of cherry. A role of the anion itself has sometimes been directly implicated in pathogen resistance.

Calcium nitrate as a means of reducing pathogen severity has been criticized as the nitrogen in this material can stimulate additional shoot growth and potentially increase disease severity (Wojcik 2001). Such a response was not recorded in this investigation, as calcium nitrate application reduced leaf and fruit scab severity in both the 2006 and 2007 trials. Chloride is widely used as a means of sterilizing long-term, stored food products, against bacterial and fungal infection. Due to the toxic nature of the chloride ion against mammalian tissue the use of chloride alone as a plant protection product has limited applicability (Fixen 1993). Calcium chloride is also a caustic salt that can corrode sprayer parts (Fixen 1993).

Boron has been shown to be an important compound in influencing disease reduction caused by several root and foliar pathogens such as tan spot disease of wheat [Drechslera tritici-repentis (Died.) Shoem.], club root of cabbages (Plasmodiophora brassicae Woronin), and Eutypa dieback of grapevines (Eutypa lata) (Dixon and Webster 1988; Rolshausen and Gubler 2005; Kostas and Dordas 2006).

In field trials, calcium sulfate application was found to have had an effect on soil moisture tension by affecting the soil matrix potential, making the soil environment less conducive to Phytophthora infection and survival. Applications of calcium sulfate have also been shown to reduce disease severity of Phytophthora infestans (potato blight), and Erwinia amylovora (black leg of potato), the bacterium also responsible for fire blight of fruit trees and potato scab (McGuire and Kelman 1984; McGuire and Kelman 1986; Bain et al. 1996; Olsson 1998). The influence of protein based amino acids as plant protection compounds has received little attention due to the expense nature of the product; however, the nonprotein amino acid DL-3-amino-n-butanoic acid was found to provide $>95 \%$ protection against $P$. infestans when sprayed onto tomato plants (Cohen 1994). Likewise low molecular weight proteins (elicitins) have been shown to possess systemic acquired resistance inducing activity against a range of plant pathogens (Percival 2001).

As the calcium products used in this investigation are classified as fertilizers then they are not, at least in the UK, subject to the stringent legislative restrictions that relate to the use and application of synthetic fungicides. This also means calcium products can be used in management programs against foliar pathogens of urban trees for which no fungicides are registered. This would be of fundamental importance in the UK where anthracnose of willow [Marssonina salicicola (Bres.) Magnus] and London Plane [Apiognomonia veneta (Sacc. et Speg. Hohnel], leaf spot of cherry [Blumeriella jaapii (Rehm) v. Arx.] and blossom wilt of cherry [Monilinia laxa (Aderh. and Ruhland) Honey], are increasing in severity on an annual basis, resulting in deaths of heavily infected trees. Likewise, calcium products cost in general 40\%-60\% less than conventional fungicides. Viewed in this context, the development of calcium-based products may provide a useful addition to existing methods of plant pathogen control.

In conclusion, current management strategies for foliar pathogens throughout the United Kingdom and Europe are heavily dependent upon repeat fungicide applications. In order to improve the effectiveness and sustainability of current strategies, a new holistic approach has been studied. These research findings confirm that foliar calcium applications offer a useful, practical supplement to existing scab fungicide programs that can be easily implemented with existing spray technologies and may have applicability for the control of other foliar pathogens of ornamental and urban trees. However, the ability of calcium alone to reduce scab must not be overstated, and should not be used as a replacement for conventional fungicides.

Acknowledgments. The author is grateful for funding in part from the TREE Fund (Hyland Johns Grant).

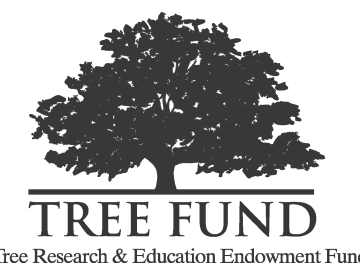

\section{LITERATURE CITED}

Akbudak N., H. Tezcan, B. Akbudak, and V. Seniz. 2006. Effect of harpin protein on plant growth parameters, leaf chlorophyll, leaf colour and percentage rotten fruit of pepper plants inoculated with Botrytis cinerea. Scientia Horticulturae 109(2):107-112.

Bain, R.A., P. Millard, and M.C.M. Perombelon. 1996. The resistance of potato plants to Erwinia carotovora subsp.atroseptica in relation to their calcium and magnesium content. Potato Research 39(1):185193.

Berbezy, P., L. Legendre, and A. Maujean. 1996. Purification and characterisation of alpha-amylase from vine shoot inter-nodes. Plant Physiology and Biochemistry 34(3):353-361.

Berrie, A.M., and X.M. Xu. 2003. Managing apple scab (Venturia inaequalis) and powdery mildew (Podosphaera leucotricha) using Adem (TM). International Journal of Pest Management 9:243-249.

Biggs, A.R., M.M. El-Kholi, S. El-Neshawy, and R. Nickerson. 1997. Effects of calcium salts on growth, polygalacturonase activity, and infection of peach fruit by Monilinia fructicola. Plant Disease 81:399-403.

Børve, J., L. Sekse, A. Stensvand, and J. Ystaas. 1998. Cuticular fractures as infection sites of Botrytis cinerea in sweet cherry fruits. Acta Horticulturae 468:737-739.

Børve, J., L. Sekse, and A. Stensvand. 2000. Cuticular fractures promote postharvest fruit rot in sweet cherries, Plant Disease 84:1180-1184.

Butt D.J., A.A.J. Swait, and J.D. Robinson. 1990. Evaluation of fungicides against apple powdery mildew and scab. Tests of Agrochemicals and Cultivars 11. Annals of Applied Biology (supplement) 116:34-35.

Chardonnet, C.O., C.E. Sams, and W.S. Conway. 1999. Calcium effect on the mycelial cell walls of Botrytis cinerea. Phytochemistry 52:967-973.

Chardonnet, C.O., C.E. Sams, R.N. Trigiano, and W.S. Conway. 2000. Variability of three isolates of Botrytis cinerea affects the inhibitory effects of calcium on this fungus. Phytopathology 90:769-774.

Christiansen, E., P. Karokene, A.A. Berryman, V.R. Franceschi, T. Krekling, F. Lieutier, A. Lonneborg, and H. Solheim. 1999. Mechanical injury and fungal infection induce acquired resistance in Norway spruce. Tree Physiology 19:399-403.

Cline, R.A., and G. Tehrani. 1973. Effects of boron and calcium sprays and of mulch on cracking of Italian prune. Canadian Journal of Plant Science 53:827-831.

Cohen, Y. 1994. Local and systemic control of Phytophthora infestans in tomato plants by DL-3-amino-n-butanoic acids. Phytopathology 84(1):55-59. 
Conway, W.S., C.E. Sams, J.A. Abbott, and B.D. Bruton. 1991. Postharvest calcium treatment of apple fruit to provide broad-spectrum protection against postharvest pathogens. Plant Disease 75:620-622.

Cuthbertson, A.G.S., and A.K. Murchie. 2003. The impact of fungicides to control apple scab (Venturia inaequalis) on the predatory mite Anystis baccarum and its prey Aculus schlechtendali (apple rust mite) in Northern Ireland Bramley orchards. Crop Protection 22:1125-1130.

Dixon, G.R., and M.A. Webster. 1988. Antagonistic effects of boron, calcium and $\mathrm{pH}$ on pathogenesis caused by Plasmodiophora brassicae Woronin (clubroot) - a review of recent work. Crop Research 28(1):83-95.

Durham, R.E., R.C. McNiel, J.R. Hartman, D.A. Potter, and W.M. Fountain. 1999. The Flowering Crabapple. Cooperative extension service technical note ID 68. University of Kentucky, College of Agriculture, USA.

Elmer, P.A.G., T.M. Spiers, and P.N. Wood. 2006. Effects of pre-harvest foliar calcium sprays on fruit calcium levels and brown rot of peaches. Crop Protection 26(1):11-18.

Fixen, P.E. 1993. Crop responses to chloride. Advances in Agronomy 50:107-150.

Forbes-Smith, M. 1999. Induced resistance for the biological control of postharvest diseases of fruit and vegetables. Food Australia 51: 382-385.

Glenn, D.M., G.J. Puterka, S.R. Drake, T.R. Unruh, A.L. Knight, P. Baherle, E. Prado, and T. Baugher. 2001. Particle film application influences apple leaf physiology, fruit yield, and fruit quality. Journal of the American Society of Horticultural Science 126:175-181.

Glenn, D.M., G.J. Puterka, T. Van der Zwet, R.E. Byers, and C. Feldhake. 1999. Hydrophobic particle films: A new paradigm for suppression of arthropod pests and plant diseases. Journal Economic Entomology 92:759-771.

Hagan, A.K., and J.R. Akridge. 2007. Synthetic and biorational fungicides compared for the control of three foliar diseases of flowering dogwood. Journal Environmental Horticulture 25:157-165.

Ilhan, K., U. Arslan, O.A. Karabulut. 2006. The effect of sodium bicarbonate alone or in combination with a reduced dose of tebuconazole on the control of apple scab. Crop Protection 25:963-967.

Ippolito, A., L. Schena, I. Pentimone and F. Nigro. 2005. Control of postharvest rots of sweet cherries by pre-and postharvest applications of Aureobasidium pullulans in combination with calcium chloride or sodium bicarbonate. Postharvest Biology and Technology 36:245-252.

Kohle, H., F. Jeblick, F. Poten, W. Blaschek, and H. Kauss. 1985. Chitosan-elicited callose synthesis in soy bean cells as $\mathrm{a} \mathrm{Ca}_{2}{ }^{+}$-dependent process. Plant Physiology 77:544-551.

Kostas, B.S., and C. Dordas. 2006. Effect of foliar applied boron, manganese and zinc on tan spot in winter durum wheat. Crop Protection 25(7):657-663.

Legge, R.L., E. Thompson, J.E. Baker, and M. Lieberman. 1982. The effect of calcium on the fluidity and phase properties of microsomal membranes isolated from post climacteric Golden Delicious apples. Plant Cell Physiology 23:161-169.

Levene, H. 1960. Robust tests for equality of variances. In: I. Olkin, S.G. Ghurye, W. Hoeffding, In: W.G. Madow and H.B. Mann (Eds.), Contributions to Probability and Statistics. Stanford University Press, Stanford, CA.

Lichtenthaler, H.K., and A.R. Wellburn. 1983. Determinations of total carotenoids and chlorophylls $\mathrm{a}$ and $\mathrm{b}$ of leaf extracts in different solvents. Biochemical Society Transactions 11:591-593.

Kitao, M., T.T. Lei, T. Koike. 1998. Application of chlorophyll fluorescence to evaluate Mn tolerance of deciduous broad-leaved tree seedlings native to northern Japan. Tree Physiology. 18:135-140.
McGuire, R.C., and A. Kelman. 1984. Reduced severity of Erwinia soft rot in potato tubers with increased calcium content. Phytopathology 74(10): 1250-1256

McGuire, R.C., and A. Kelman. 1986. Calcium in potato tuber cell walls in relation to tissue maceration by Erwinia carotovora pv. atroseptica. Physiology and Biochemistry 76:401-406.

Meinander, O., S. Somersalo, T. Holopainen, and R.J. Strasser. 1996. Scots Pine after exposure to elevated ozone and carbon dioxide probed by reflectance spectra and chlorophyll a fluorescence transients. Journal of Plant Physiology 148:229-236.

Miceli, A., A. Ippolito, V. Linsalata, and F. Nigro. 1999. Effect of preharvest calcium treatments on decay and biochemical changes in table grape during storage. Phytopathology Mediterranea 38:47-53.

Michailides, T.J., and D.P, Morgan. 1997. Influence of fruit-to-fruit contact on the susceptibility of French prune to infection by Monilinia fructicola. Plant Disease 81(12):1416-1424.

Monroy, A.F., F. Sarhan, and R.S. Dhindsa. 1993. Cold-induced changes in freezing tolerance, protein phosphorylation, and gene expression. Plant Physiology 102:1227-1235.

Nicholas, A.H., R. Spooner-Hart, and R.A Vickers. 2003. Control of woolly aphid, Eriosoma lanigerum (Hausmann) (Hemiptera: Pemphigidae) on mature apple trees using insecticide soil-root drenches. Australian Journal Entomology 42:6-11.

Olsson, K. 1988. Resistance to gangrene (Phoma exigua var. foveata) and dry rot (Fusarium solani var. coeruleum) in potato tubers. 1. The influence of pectin-bound magnesium and calcium. Potato Research 31:413-422.

Percival, G.C. 2001. Induction of systemic acquired disease resistance in plants: Potential implications for disease management in urban forestry. Journal of Arboriculture 27(4):181-193.

Percival, G C., and S. Boyle. 2005. Evaluation of microcapsule trunk injections for the control of apple scab and powdery mildew. Annals Applied Biology 147:119-127.

Percival, G C., and I. Haynes. 2008. The Influence of systemic inducing resistance chemicals for the control of oak powdery mildew (Microsphaera alphitoides) applied as a theraputic treatment. Arboriculture \& Urban Forestry 34(5):191-200.

Price, A.H. 1990. A possible role for calcium in oxidative plant stress. Free Radical Research Communications 10:345-349.

Raesse, J.T. 1997. Cold tolerance, yield and fruit quality of d'Anjou pears influenced by nitrogen fertilizer rates and time of application. Journal of Plant Nutrition 20:1007-1025.

Rolshausen, P.E., and W.D. Gubler. 2005. Use of boron for the control of Eutypa dieback of grapevines. Plant Disease 89(7):734-738

Steponkus, P.L. 1984. Role of the plasma membrane in freezing injury and cold acclimation. Annual Review of Plant Physiology 35:543-84.

Swait, A.A.J., and D.J. Butt. 1990. Fungicides as antisporulants against apple powdery mildew and scab. Tests of Agrochemicals and Cultivars 11. Annals Applied Biology (supplement) 116:36-37.

Walters, D.R. 2006. Disguising the leaf surface: the use of leaf coatings for plant disease control. European Journal of Plant. Pathology 114:255-260.

Willits, D.H., and M.M. Peet. 2001. Using chlorophyll fluorescence to model leaf photosynthesis in greenhouse pepper and tomato. Acta Horticulturae 507:311-315.

Wojcik, P. 2001. Dabrowicka prune fruit quality as influenced by calcium spraying, Journal of Plant Nutrition 24:1229-1241. 
Glynn C. Percival (corresponding author)

Plant Physiologist/Technical Support Specialist

R.A. Bartlett Tree Research Laboratory, Europe

The University of Reading

2 Early Gate, Whiteknights

Reading, RG6 6AU, United Kingdom

gpercival@bartlettuk.com

Ian Haynes

Arboricultural Representative

Bartlett Tree Experts Company (Ireland) Ltd.

Windmill View

Blackchurch

Rathcoole

Co Dublin

Republic Of Ireland

ihaynes@bartlettirl.com

Zusammenfassung. Ein Ziel des Pflanzenschutzes in der Baumpflegeindustrie sollte sein, die Anzahl der aktiven Inhaltsstoffe bei synthetischen Fungiziden, die innerhalb einer Wachstumsperiode verwendet wurden, zu eliminieren oder zumindest zu reduzieren. Der Inhalt dieser Forschungsarbeit ist es, ein nicht-fungizides SchadensregerManagement-System mittels der Hypothese zu bewerten, dass ein Apfelschorf-Fungizid-Einsatz ersetzt durch Calcium die Befallsdichte mit Frucht- und Blattschorf reduziert. Zusätzlich wurde in einer separaten Studie untersucht, ob eine Beziehung existiert zwischen CalciumKonzentrationen im Blattgewebe von resistenten, weniger anfälligen und ganz empfindlichen Apfelarten und ihren Varietäten bezüglich einer Apfelschorfinfektion. Eine Anzahl von kommerziell erhältlichen Calcium-Produkten wurde auf Crown-Gold-Apfelbäume in vier unterschiedlichen Wachstumsstadien (Knospung, $90 \%$ iger Abfall der Blütenblätter, früher Fruchtabwurf und zwei Wochen nach den frühen Abwurf) appliziert. Eine vergleichende Bewertung des synthetischen Fungizids Penconazol, welches im kommerziellen Apfelanbau gegen Apfelschorf eingesetzt wird, wurde ebenfalls geleitet. Das Experiment wurde in 2006 an der Universität von Reading (UK) durchgeführt und im Jahr 2007 wiederholt. Die Applikation von Calcium-Spray reduzierte deutlich den Befall von Blättern und Früchten beim Crown-Gold-Apfel. Dennoch konnte in einer separaten Studie keine Beziehung zwischen dem Blattcalciumgehalt und der Anfälligkeit gegenüber Apfelschorf bei resistenten, weniger anfälligen und ganz empfindlichen Apfelarten aufgezeigt werden. Der größte Schutz in beiden Feldversuchen wurde durch die Applikation von Penconazol erreicht. Innerhalb der bewerteten Calcium.Produkte konnte der größte Schutz in beiden Feldversuchen durch Calciumchlorid und Calciumhydroxid erzielt werden. Die Integration von Calciumsprays in bestehende Schorfbehandlungen bietet eine nützliche Erweiterung, um die Befallsschwere bei ornamentalen Apfelbäumen, die mit anderen Applikationen gegen andere Blattkrankheiten, wie sie gelegentlich im Landschaftsbau vorkommen, zu reduzieren.

Resumen. Un objetivo del manejo de patógenos en la industria de la arboricultura debe ser eliminar o reducir la cantidad de ingredientes activos de fungicidas sintéticos usados dentro de una estación de crecimiento. El propósito de esta investigación es evaluar un sistema de manejo de patógenos no fungicida mediante la investigación de la hipótesis que remplazando un programa de aspersión de la roña del manzano con calcio reduce la severidad de la roña en hoja y fruto. Además, un estudio separado investigó si la relación entre concentraciones de calcio dentro del tejido foliar de especies de manzano resistentes, intermedias y sensibles y variedades hacia la infección. Se aplicaron un número de productos de calcio comercialmente disponibles. Árboles Crown Gold en cuatro distintos estados de crecimiento (yema, 90\% de pétalos caídos, fructificación temprana, dos semanas después de la fructificación). Se llevó a cabo también una evaluación comparativa del fungicida sintético penconazole, comercialmente usado para el control de la roña. El experimento fue realizado en 2006 y repetido en 2007 en el campo experimental de la Universidad de Reading (UK). La aplicación del spray de calcio redujo significativamente la severidad de la enfermedad en la hoja y el fruto del manzano. Crown Gold, sin embargo, en un estudio separado, no mostró relación entre el contenido de calcio foliar y la susceptibilidad del ataque de la roña entre especies de Malus resistentes, intermedias y sensibles. La mayor protección en ambos ensayos de campo fue proporcionada por el fungicida sintético penconazole. Dentro de los productos de calcio evaluados, la mayor protección en ambos ensayos de campo fue dada por cloruro de calcio e hidróxido de calcio. La integración de sprays de calcio foliar dentro de las prácticas de manejo de la roña ofrece un agregado útil para reducir la severidad de la roña en manzanos ornamentales que tiene aplicabilidad contra otras enfermedades foliares, frecuentemente encontradas en paisajes urbanos. 